\title{
Arduino-Based Mini Reed Switch Magnetic Sensor Media: Implementation in Physics Learning to Improve Students' Analyzing Ability
}

\author{
Umi Pratiwi ${ }^{*}$, Gamar Al Haddar2, Muhammad Kristiawan ${ }^{3}$ \\ 1Universitas Muhammadiyah Purworejo, Indonesia \\ 2 Universitas Widya Gama Mahakam, Indonesia \\ ${ }^{3}$ Universitas Bengkulu, Indonesia
}

Corresponding Author: Umi Pratiwi, umipratiwi@upwr.ac.id*

\section{ABSTRACT}

This article was to improve students' ability to analyze the viscosity material in implementing the Arduino-based MRSM (Mini Reed Switch Magnetic) teaching media. The researchers used a quasi

ARTICLE INFO

Article history:

Received

February 26, 2020

Revised

May 17, 2020

Accepted

June 07, 2020 experimental design in the form of non equivalent pre-test post-test group design. The instruments used were tests and observation sheets to obtain data. Data collection on theability to analyze through giving tests to students. Data were analyzed using descriptive statistics. The results showed an increase in the ability to analyze by $20 \%$. The highest assessment aspect in the first aspect is the ability of students to find problems encountered and be able to distinguish problems that fit the theme. The results of this trial produce data on the implementation of learning by $98 \%$ with a reliable category. Hence, MRSM teaching media is able to improve the ability to analyze students.

Keywords:Mini Reed Switch Magnetic, Sensor Media, Physics Learning

How to cite

Pratiwi, U., Al Hadar, U., \& Kristiawan, M. (2020). Ardunio-Based Mini Reed Switch Magnetic Sensor Media: Implementation in Physics Learning to Improve Students' Analyzing Ability. Jurnal Iqra':Kajian Ilmu Pendidikan, 5(1). 183-193. https://doi.org/10.25217/ji.v5i1.773

Journal Homepage http://journal.iaimnumetrolampung.ac.id/index.php/ji/

This is an open access article under the CC BY SA license

https://creativecommons.org/licenses/by-sa/4.0/

Published by

\section{INTRODUCTION}

The world of education is increasingly developing along with technological developments. Technology and education significantly influence each other to run according to their respective roles (Budiman, 2017). Technology as a supporting component of learning with the right target can help in improving the quality of learning (Yuberti, 2015) . Conventional education that has begun to be abandoned will be replaced by the role of technology to be applied in learning. The aim of higher education, especially in the field of tertiary education, is to improve the ability and quality of students to become professional teacher candidates (Sidik, 2016). One of the teacher's competencies is pedagogical competence. The ability is very needed by a prospective teacher to be able to assist students in developing the potential of students (Sulfemi, 2019). 
Beside the important pedagogical ability element, learning media is a supporting element and the main element in the application of developing technology right now. The problems of using media are also a basic problem in improving the quality of learning (Pribadi, 2017). The less maximal mastery of learning material can give effect of the students' competence and knowledge. The condition at the same time if there is a lack of facilities, especially learning media will also lead to inaccuracies in the learning process (Anas, 2014). This problem also arises in basic science learning due to the lack of provisions for prospective teachers to be well prepared and the lack of practical skills (Pujani, 2015).

The first problem found for the students, for instance they have difficulty representing theories or concepts that have been obtained for real-world applications. Consequently the teachers need tools that is learning media that help students to learn physics concepts (Gunada et al., 2017). This difficulty affects when students complete a problem project: they face the difficulties by linking problem identification with the solutions taken (I. G. A. Wulandari et al., 2018). The second problem was on the media or practical tools that are still conventional and the tools have a low accuracy because they have not been updated or calibrated (Erintina, 2015). One of the material temperature and heat is viscosity. It is the tool that is used for observing viscosity phenomena in basic physics practiceusing manual tools, such as stopwatches, distance measurements using the bar, and measuring cups. It causes the data obtained such as the coefficient of thickness away from the theory (Ardiansyah, 2017). Those problems affect of students' think ways and analyze in solving the problems.

To solve those problems are applying learning media as a tool for students to understand the concepts of learning process. The ongoing learning process requires learning resources and learning media (Selviani \& Anggraini, 2018). The appropriate media is accordance with a technological developments and fun learning. For instance using Arduino-based teaching media using mini reed switch magnetic (MRSM) sensors on viscosity teaching aids. The use of these sensors will increase the accuracy of the tool and be more accurate than previously done conventionally (Siegel et al., 2016). Mini reed switch magnetic sensor is an electrical switch that is operated with a magnetic field. MRSM sensors are similar as rotor molecules that work like sensors to measure fluid viscosity (López-Duarte et al., 2014). It consists of a pair of boxes on an iron metal body in a tightly closed glass envelope. Contacts can open and close when the magnetic field is brought closer (Herlambang Tryan WIcaksono \& Wanarti Rusimamto, 2019).

The sensor on the viscosity props will be used to detect the time the object falls (magnetic ball) from the top of the surface that reaches the bottom automatically and time data will be sent to Arduino. Arduino is an editor used to write programs, compile, and upload to Arduino boards (Romadhon et al., 2019). Arduino will process programs and data that have been uploaded and the results will be displayed. With sensor-based teaching aids, it is expected 
that the results of calculating the viscosity of a fluid can be maximized and the teaching aids can help students understand the concepts and materials of viscosity.

Some previous studies declared that the use of mini reed switch magnetic sensors on the teaching aids is expected to improve the ability of students to analyze and solve problems accurately. Furthermore, different from Wulandari and Rosidin' study that yeaching aids as visual aids for learning using a digital stopwatch modified with microswitch with the help of a magnet as a ball restraint when when gliding effectively helps students learn viscosity material (S. D. Wulandari \& Rosidin, 2013). While, viscosity teaching aids can be developed as learning props with two tubes containing different liquids and the heater underneath. The heater is used to heat the liquid in the tube, the time calculation uses a time sensor when the ball starts sliding down. This visual aid produces the ability of process skills with the management of learning by 97.22\% (Setyowati, 2020). Props with the same modification only ball markers appear still using conventional threads using guided descovery learning models also help students understand the concept of viscosity (Nurvitasari, 2019). In addition, the development of viscosity teaching aids for the free fall ball method assisted by the UGN 3503 hall effect sensor can also assist students in understanding the concept of viscosity (Ramadhan et al., 2016). Some of the development of viscosity visual aids have some uniqueness and weaknesses. The viscosity aids that will be developed have the advantage with a time recording system and the ball's downward track launch is more accurate than conventional systems. The accuracy of the data obtained can help produce more accurate variables so that the development of teaching aids using mini reed sensors is used to help students analyze the problems encountered in the concept of viscosity. This research focus on using Ardunio-Based Mini Read Switch Magnetic (MRSM) sensor media, especially in implementation Physics learning to improve analysing ability.

\section{METHODS}

The research design used quasi experimental design in the form of non equivalent pre-test post-test group design. This design is used to analyze the comparison of students progress before and after learning in the experimental class (Setyosari, 2016).

o1 $\times$ o2

Information:

O1 $=$ Pretest value (before treatment)

$\mathrm{X}=$ Treatment

$\mathrm{O} 2$ = post-test score (after treatment)

Data in this study were obtained through tests in giving question for the students. Questions are designed to measure students' ability. Wang \& Chiew (2010) suggested that analysing of students' ability can use cognitive process, for instance: 
Ardunio-Based Mini Reed Switch Magnetic Sensor Media: Implementation in Physics Learning to Improve Students' Analyzing Ability

Table 1. Cognitive Process on Ability's Analyzing

\begin{tabular}{|l|}
\hline Cognitive Processes and Indicators \\
\hline $\begin{array}{l}\text { 1. Differentiate } \\
\text { a. Focus the problem } \\
\text { b. Find the equation of the problem }\end{array}$ \\
\hline 2. Organizing \\
a. Connecting the problem \\
b. Focusing in Outline the problem \\
\hline 3. Attribute \\
a. Describing the problem \\
b. Determining \\
the intent of a problem
\end{tabular}

Analysis of the effectiveness test data was carried out using statistical analysis of the research data with the n-gain test to find out an increase between pre-test and post-test. The amount of increase is calculated by the normalized N-Gain ume (Myers \& Lorch, 2010), namely:

$$
g=\frac{s_{f}-s_{i}}{100-s_{i}}
$$

information:

$g \quad=$ normalized gain

$s_{f}=$ post-test score

si $=$ pre-test score

$100=$ ideal score

The result $\mathrm{N}$-gain calculation, then interpreted using the classification as in Table 2.

Table 2. Categories Normalized N-gain Scores

\begin{tabular}{|l|l|}
\hline Criteria & Conclusion \\
\hline$g>0,7$ & High \\
\hline $0,3<g \leq 0,7$ & Medium \\
\hline$g \leq 0,3$ & Low \\
\hline
\end{tabular}

While the calculating feasibility of learning using Calculating the value of Percentage Agreement (PA). Percentage Agreement value is used to calculate the reliability of the results of research on the implementation of learning conducted during the learning process. According to Wardhani (2018) the Percentage Agreement can be determined by the following equation.

$$
\text { Percentage Agreement }(P A)=\left(1-\frac{A-B}{A+B}\right) \times 100 \%
$$


Information :

PA $=$ Percentage Agreement

A $=$ higher score than observer

$\mathrm{B}=$ lower score than observer

The categories of PA can be converted based on the table below.

Table 3. Range of PA Category Values

\begin{tabular}{|l|l|}
\hline Value Range & Category \\
\hline $76-100$ & Reliable \\
$51-75$ & Middle \\
$26-50$ & Less \\
$0-25$ & Low \\
\hline
\end{tabular}

\section{RESULT AND DISCUSSION}

Arduino-based teaching media using MRSM (mine reed switch magnetic) sensors on viscosity material have been implemented in physics learning. Viscosity is an important variable in static fluid. Many obstacles when students understand the material viscosity related to applications in everyday life with real applications. To better understand the material practiced in basic physics practicum courses. Constraints faced mainly in conventional viscosity practicum tools, such as inaccurate time calculations when the object starts sliding through the liquid and the end when it passes through the liquid, this affects the calculation of the amount of viscosity or viscosity of the liquid. Viscosity is closely related to the ability of fluids to be able to flow through obstacles or obstacles, so that it will cause friction between the surface of the liquid with other objects when passing through it (Heinisch et al., 2014).

The implementation of the media using the MRSM sensor on viscosity material is to overcome the constraints of students' ability in applying theory to the realm of fact and the existence of practical tools that are still conventional. This student's ability has an impact on the ability to solve the faced problems that are influenced by the ability of students in analsing the problems. Ability's analysing will give an affect the provided solution. The ability in analysing consists of five essay questions and before testing an expert is assessed or validated. The results of validation questions about the ability in analyze the students as follows. 
Ardunio-Based Mini Reed Switch Magnetic Sensor Media: Implementation in Physics Learning to Improve Students' Analyzing Ability

Figure 1. Validation Score of the Ability to Analyze

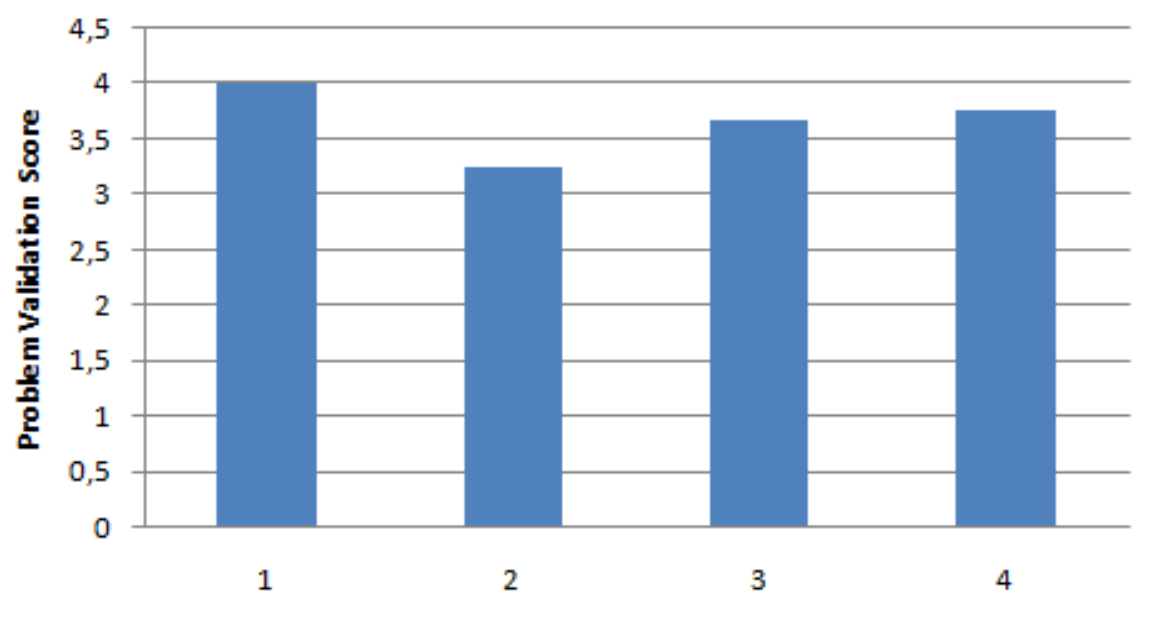

The validation results with four aspects of the assessment resulted in an average value of 3.52, which is included in a good category. These four aspects with the lowest value is in the aspect of conformity with the ability's analysing indicators. This second evaluation aspect gets a score 3.25 in good category. Based on Table 1, the results of the validation in geting a low score, on the second indicator is organizing between one problem with another. While the 1st and 3rd indicators can be related to the completion of answers by students. The questions that are made should show increasing difficulty and follow the submission stages given from simple concepts to more complex concepts.

The initial stage of the implementation of the viscosity teaching media using the MRSM sensor was tested in a limited class to find out the student's initial response to the media. The limited test is conducted on 7th semester students before going to the actual experimental class. Response data about arduino-based viscosity teaching media in using MRSM sensors used questionnaire data. The questionnaire data given to students consisted of three aspects of assessment, namely benefits, presentation of tools, and physical appearance. The results of the evaluation of arduino-based viscosity teaching media using the MRSM sensor are as follows. Table of Results of Student Response Evaluation of Arduino-based viscosity teaching media using MRSM sensors.

Table 4. Repaitulation of Student Response Evaluation of Teaching Media

\begin{tabular}{|c|c|}
\hline Assessment Aspects & Score \\
\hline The benefits & $88 \%$ \\
Presentation of tools & $83 \%$ \\
Physical appearance & $82 \%$ \\
\hline
\end{tabular}

Table above can be analysed the acquisition of the highest score in the aspect of benefit assessment. It is accordance with the obstacles that have been faced with conventional viscosity practicum equipment using only beaker and 
stopwatch. Consequently, it produces the data that is far from the theory. Practicum results obtained from conventional practicums such as the coefficient of viscosity of some fluids such as oil and cooking oil are not in accordance with the theory. Students feel greatly helped by the presence of this viscosity teaching media, such as measuring time and distance using more precise digitizing media (Romadhon et al., 2019).

The next stage is the implementation of arduino-based teaching media using MRSM sensors in the experimental class, namely the fifth semester students of physics education. Before learning the treatment class begins, pretest questions about the material of viscosity are held. This preliminary test is to find out the students' abilities and initial understanding of the material on viscosity. After the pre test was completed, the treatment was carried out on the implementation of Arduino based teaching media using the MRSM sensor and then at the end of the study a post test was held. The final test is conducted to determine the ability of the final understanding of the material viscosity and the ability to analyze students, after the treatment is run. Pre test and post test results can be analysed in the table below.

Table 5. Recapitulation results of the pres test and post test scores Students' Ability in Analsing

\begin{tabular}{|ccc|c|}
\hline $\begin{array}{c}\text { The Ability to } \\
\text { Analyze }\end{array}$ & $\begin{array}{c}\text { Pre- } \\
\text { TestScore }\end{array}$ & $\begin{array}{r}\text { Post-Test } \\
\text { Score }\end{array}$ & N-gain \\
\hline Ist Aspect & 61,88 & 80,63 & 0,492 \\
2nd Aspect & 66,25 & 76,67 & 0,309 \\
3rd Aspect & 69,79 & 79,79 & 0,331 \\
\hline Total & 65,97 & 79,03 & 0,377 \\
\hline
\end{tabular}

The table above shows that the students' ability to analyze scores for pretest and post-test. The ability to analyze in the first aspect gets the highest increase in value by $30 \%$, this ability allows students to write problems and find similarities related to those problems. The lowest analytical ability with an increase of $14 \%$ in the $3 \mathrm{rd}$ aspect, this ability is the ability to attribute (Hidayat, 2018). Able to contribute is the ability of students to describe the problem and determine the implicit intent in the problem presented. This ability is seen when students can mention the variables contained and represent in the form of variables and physical quantities. The chart of permissions per aspect can be seen in the graph below. 
Figure 2. Ability to Analyze Scores for Three Aspects

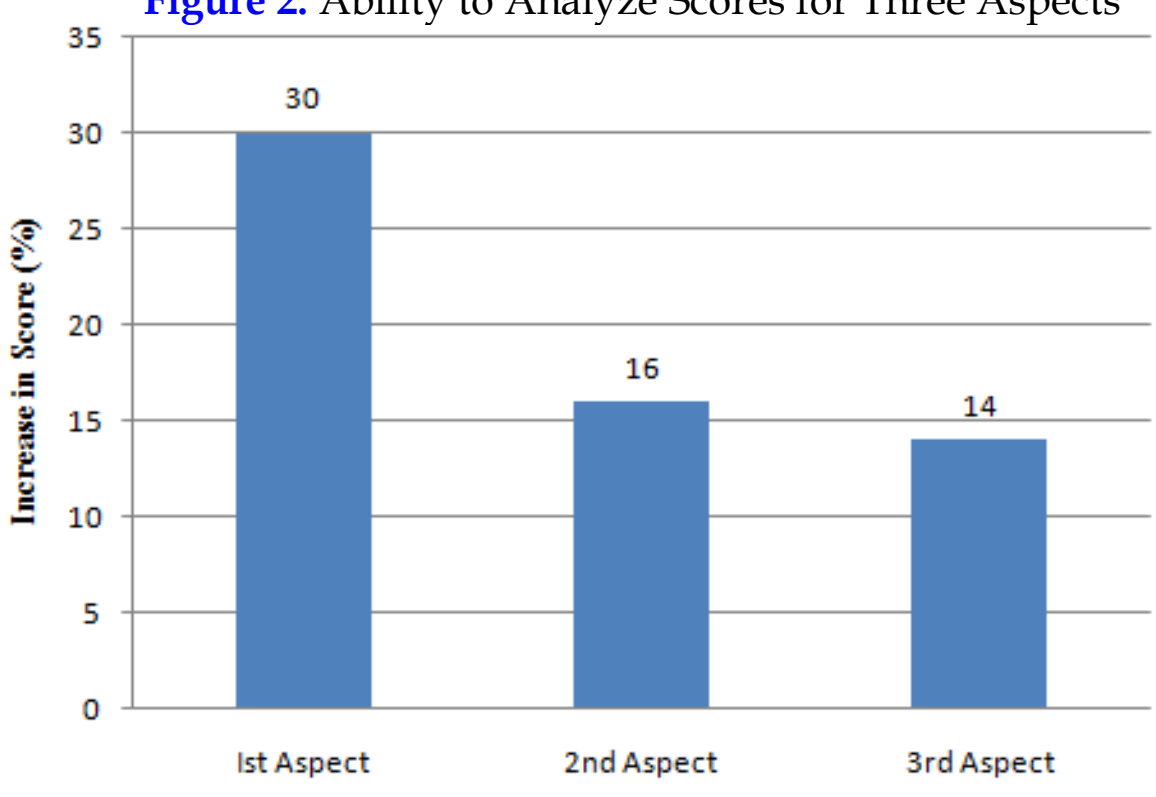

The learning process in the experimental class with the implementation of teaching media is also obtained information related to the implementation of learning. Aspects observed in the introduction, content, and closing aspects. Data obtained by the implementation of learning was carried out by two observers. Data on the implementation of learning is presented in the table below.

Table 6. Recapitulation of Learning Implementation Scores

\begin{tabular}{|c|c|c|}
\hline Assessment Aspects & Observer 1 & Observer 2 \\
\hline Preliminary & 21 & 22 \\
Content & 33 & 29 \\
Closing & 3 & 4 \\
\hline Amount & 57 & 55 \\
\hline
\end{tabular}

Based on the table it can be known that in observer 1 the score obtained in the preliminary aspect is 21 , the content aspect gets a score of 33 and the closing aspect gets a score of 3 with a total overall score of 57 . While the observer 2 , in the preliminary aspect gets a value of 20, aspects of contents 33 and closing 4 . So it obtains a total score 55. Then the data is processed to obtain the value of the Percentage Agreement (PA) using equation 11. After counting using equation 11, the Pecentage Agreement (PA) value of $98 \%$ is obtained. Based on table 7 , the value of $98 \%$ is in the range of $78 \%-100 \%$ which is included in the reliable category.

The application of viscosity learning media that has been applied in learning physics produces a significant analysis ability of student. Students can analyze the concept of viscosity that is projected by students. The accuracy of the viscosity teaching aids that have been used for using time counts and mini reed sensors is better than using conventional media (Nurvitasari, 2019), 
teaching aids that were developed by (Nurvitasari, 2019), producing viable tools for learning the physics of viscosity material. So that with these props students can analyze the concept or theory of viscosity in theory and experiment.

\section{CONCLUSIONS}

Arduino-based MRSM sensor teaching media has been implemented in physics learning in physics education students. The results in an increase in the ability to analyze $20 \%$ of the initial score. The highest assessment aspect in the first aspect is the ability of students to find problems encountered and be able to distinguish problems that fit the theme. The results of this trial produce data on the implementation of learning by $98 \%$ with a reliable category.

\section{ACKNOWLEDGMENTS}

The researchers would like to thank Dr. Rofiq Nurhadi as the Chancellor of Muhammadiyah University Purworejo who has provided motivation to the authors to complete this research. Thank you for the Institute for Research and Community Service (LPPM) Muhammadiyah University Purworejo who gave permission to conduct this research. Thanks also go to the students of the Physics Education Study Program, Tariska and Very for their contribution in helping to collect data

\section{AUTHOR CONTRIBUTION STATEMENTS}

This research is the result of ongoing research in the last two years for the Aplikom and Computational Physics courses in the development of arduinobased learning media as a medium to improve students' abilities in the development of physics teaching media.

\section{REFERENCES}

Anas, M. (2014). Alat peraga dan media pembelajaran. Muhammad Anas. Google Scholar.

Wang, Y., \& Chiew, V. (2010). On the cognitive process of human problem solving. Cognitive systems research, 11(1), 81-92. https:// doi.org/10.1016/j.cogsys.2008.08.003

Ardiansyah, D. (2017). Perancangan Dan Penerapan Sensor Kumparan untuk Percobaan Viskositas dengan Metode Bola Jatuh. Inovasi Fisika Indonesia, 6(1). Google Scholar.

Budiman, H. (2017). Peran teknologi informasi dan komunikasi dalam pendidikan. Al-Tadzkiyyah: Jurnal Pendidikan Islam, 8(1), 31-43. DOI: https:/ / doi.org/10.24042/atjpi.v8i1.2095.

Erintina, M. (2015). Pengaruh Model Pembelajaran Expository Berbantuan Alat Peraga Terhadap Hasil Belajar Fisika Siswa Kelas VIII SMPN 21 Mataram Tahun Pelajaran 2014/2015. Ganec Swara, 9(1), 140-144. .Google Scholar.

Gunada, I. W., Sahidu, H., \& Sutrio, S. (2017). Pengembangan perangkat pembelajaran fisika berbasis masalah untuk meningkatkan hasil belajar 
Ardunio-Based Mini Reed Switch Magnetic Sensor Media: Implementation in Physics Learning to Improve Students' Analyzing Ability

dan sikap ilmiah mahasiswa. Jurnal Pendidikan Fisika Dan Teknologi, 1(1), 38-46. DOI: http:/ / dx.doi.org/10.29303/jpft.v1i1.233.

Heinisch, M., Reichel, E., Dufour, I., \& Jakoby, B. (2014). A u-shaped wire for viscosity and mass density sensing. Sensors and Actuators A: Physical, 214, 245-251. DOI: https:/ / doi.org/10.1016/j.sna.2014.04.020.

Herlambang Tryan WIcaksono, R., \& Wanarti Rusimamto, P. (2019). Perancangan Sistem Kontrol Posisi Sumbu Elevasi Gun Pada Turret-Gun Menggunakan Kontroler Pid Berbasis Arduino Mega. JURNAL TEKNIK ELEKTRO, 9(1). Google Scholar

Hidayat, T. (2018). Pengaruh Penggunaan Lembar Kerja Siswa (LKS) Berbasis Model Problem Solving Polya Pada Konsep Fluida Dinamis Terhadap Kemampuan Menganalisis Siswa. Jurnal Gemaedu, 3(2), 111-121. Google Scholar.

López-Duarte, I., Vu, T. T., Izquierdo, M. A., Bull, J. A., \& Kuimova, M. K. (2014). A molecular rotor for measuring viscosity in plasma membranes of live cells. Chemical Communications, 50(40), 5282-5284. DOI:https:/ / doi.org/10.1039/C3CC47530A.

Myers, J. L., Well, A., \& Lorch, R. F. (2010). Research design and statistical analysis. Routledge Google Scholar.

Nurvitasari, S. (2019). Pengembangan Alat Peraga Viskositas Sebagai Media Pembelajaran Fisika Dengan Model Pembelajaran Guided Discovery Di Sma. Inovasi Pendidikan Fisika, 8(2). Google Scholar.

Pribadi, B. A. (2017). Media \& teknologi dalam pembelajaran. Prenada Media. Google Scholar.

Pujani, N. M. (2015). Pengembangan Perangkat Praktikum Ilmu Pengetahuan Bumi dan Antariksa Berbasis Kemampuan Generik Sains untuk Meningkatkan Keterampilan Laboratorium Calon Guru Fisika. JPI (Jurnal Pendidikan Indonesia), 3(2). http://dx.doi.org/10.23887/jpiundiksha.v3i2.4463

Ramadhan, D., Serevina, V., \& Raihanati, R. (2016). Pengembangan alat praktikum viskometer metode bola jatuh bebas berbasis sensor efek hall UGN3503 sebagai media pembelajaran fisika. 5, SNF2016-RND. Google Scholar.

Romadhon, N., Pratiwi, U., \& Al Hakim, Y. (2019). Keefektifan Alat Peraga Viskositas Dengan Sensor Mini Reed Switch Magnetic Berbasis Arduino Untuk Meningkatkan Kemampuan Analyzepeserta Didik. Muslim Heritage, 4(2). DOI: 10.21154/muslimheritage.v4i2.1765.

Selviani, S., \& Anggraini, W. (2018). Pengembangan Media Pembelajaran Majalah Fisika sebagai Suplemen Pembelajaran Terintegrasi Nilai Keislaman. Indonesian Journal of Science and Mathematics Education, 1(1), 79-87. DOI: https:// doi.org/10.24042/ijsme.v1i1.2478.

Setyowati, D. (2020). Pengembangan Alat Peraga Viskositas untuk Melatihkan Keterampilan Proses Sains pada Peserta Didik di SMA. Inovasi Pendidikan Fisika, 9(1). Google Scholar.

Sidik, F. (2016). Guru Berkualitas Untuk Sumber Daya Manusia Berkualitas. Tadbir: Jurnal Manajemen Pendidikan Islam, 4(2), 109-114. Google Scholar. 
Siegel, J. E., Erb, D. C., Ehrenberg, I. M., Jain, P., \& Sarma, S. E. (2016). Local viscosity control printing for high-throughput additive manufacturing of polymers. 3D Printing and Additive Manufacturing, 3(4), 252-261. https://doi.org/10.1089/3dp.2016.0037.

Sulfemi, W. B. (2019). Kemampuan Pedagogik Guru. Google Scholar.

Setyosari, H. P. (2016). Metode penelitian pendidikan \& pengembangan. Prenada Media. Google Scholar.

Wardhani, S. W. (2018). Pengembangan Media Scrapbook Pada Materi Pengelompokan Hewan Untuk Siswa Kelas III Sekolah Dasar. JS (JURNAL SEKOLAH), 2(2), 124-130. DOI: OI: https:/ / doi.org/10.24114/js.v2i2.9934.

Wulandari, I. G. A., Sa'dijah, C., As'ari, A. R., \& Rahardjo, S. (2018, June). Modified guided discovery model: a conceptual framework for designing learning model using guided discovery to promote student's analytical thinking skills. In Journal of Physics: Conference Series (Vol. 1028, No. 1, p. 012153). IOP Publishing.. Google Scholar.

Wulandari, S. D., \& Rosidin, U. (2013). Pengembangan Alat Peraga Fisika Pada Materi Viskositas Sebagai Media Pembelajaran. Jurnal Pembelajaran Fisika, 1(4). Google Scholar.

Yuberti, Y. (2015). Online Group Discussion pada Mata Kuliah Teknologi Pembelajaran Fisika. Jurnal Ilmiah Pendidikan Fisika Al-Biruni, 4(2), 145153. DOI: https:// doi.org/10.24042/jpifalbiruni.v4i2.88.

\section{Copyright Holder :}

(c) Pratiwi, U., Al Hadar, U., \& Kristiawan, M. (2020).

First Publication Right :

(C) Jurnal Iqra' : Kajian Ilmu Pendidikan

This article is under:

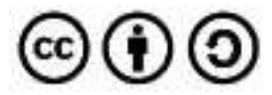

